\title{
Seed rain generated by bats under Cerrado's pasture remnant trees in a Neotropical savanna
}

\author{
J. Ragusa-Netto ${ }^{a}$ and A. A. Santos ${ }^{b}$

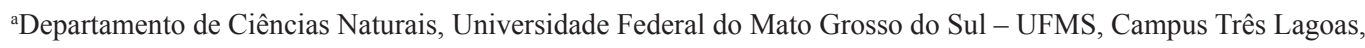 \\ Av. Ranulpho Marques Leal, 3484, CP 210, CEP 79610-100, Três Lagoas, MS, Brazil

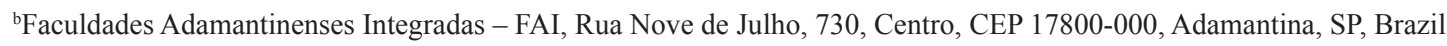 \\ *e-mail: jragusanetto@yahoo.com
}

Received: December 10, 2013 - Accepted: August 12, 2014 - Distributed: November 30, 2015

(With 3 figures)

\begin{abstract}
In this study we described the seed rain generated by bats under four Cerrado's tree species common within pastures, Buchenavia tomentosa, Couepia grandiflora, Licania humilis and Qualea grandiflora. We analyzed the similarity among the four tree species in terms of seed rain composition, and compared the number of seeds and seed species deposited under them. Besides that, we assessed the relationship between seed rain intensity and the density of each tree species. Then, we randomly selected 10 mature trees of each species to sample seed rain. We recorded a total of 4892 bat dispersed seeds from 11 species. Also, we observed that along the year seed deposition varied substantially under all trees. At least two seed sub-communities could be distinguished according to tree species used by bats as feeding roost. One related to Conepia grandiflora and Licania humilis, and the other to Buchenavia tomentosa and Qualea grandiflora trees. The variability of seed rain composition in any particular tree and the range of actual seed fall into a particular species indicate patchiness in seed rain, and the overall results appear to be consistent in terms of a substantial and diverse seed rain generated by bats in a highly anthropized landscape. This is the first study concerning seed dispersal by bats in modified Brazilian Cerrado, one of the most endangered biomes in the world. In this respect, by preserving a dense and diverse collection of remnant trees within today's pastures may, potentially, contribute to a faster Cerrado recovery in extensive areas that can be reclaimed for restoration in the future.
\end{abstract}

Keywords: seed dispersal, seed diversity, frugivory, bat feeding roost, recruitment foci.

\section{Chuva de sementes gerada por morcegos sob árvores remanescentes do Cerrado no Brasil Central}

\section{Resumo}

Neste estudo descrevemos a chuva de sementes gerada por morcegos sob quatro espécies arbóreas comuns em pastagens no Cerrado (Bouchenavia tomentosa, Couepia grandiflora, Licania humilis e Qualea grandiflora). Também, analisamos a similaridade quanto à composição da chuva de sementes depositada sob as quatro espécies arbóreas, além da relação entre a intensidade da chuva de sementes e densidade de cada espécies arbóreas. Para tanto, selecionamos aleatoriamente 10 árvores por espécie que fossem reprodutivamente maduras, para amostrar a chuva de sementes. Registramos um total de 4892 sementes, pertencentes a 11 espécies de plantas, dispersadas por morcegos. Durante o ano a deposição de sementes variou substancialmente sob todas as árvores amostradas. Duas sub-comunidades de sementes emergiram associadas às espécies arbóreas usadas por morcegos como abrigo de alimentação. Uma relacionada à Couepia grandiflora e Licania humilis, e outra relacionada à Buchenavia tomentosa e Qualea grandiflora. A variabilidade da composição da chuva de sementes sob qualquer uma das árvores, bem como a amplitude dessa chuva sob cada espécie de árvore indicou um padrão heterogêneo e intenso de deposição de uma coleção diversa de sementes em uma área altamente antropizada. Neste aspecto, a manutenção de uma rica e densa coleção de árvores remanescentes nas áreas de pastagens pode contribuir, potencialmente, para uma regeneração mais rápida do Cerrado em extensas áreas que podem requerer planos de restauração futuramente.

Palavras-chave: dispersão de sementes, diversidade de sementes, frugivoria, abrigo de alimentação de morcegos, foco de recrutamento. 


\section{Introduction}

Seed rain is the initial phase of tropical vegetation organization and structure (Gorchov et al., 1993; Wright et al., 2005). Assessing the processes that generate different patterns of seed rain are essential steps toward understanding the organization and diversity of plant communities (Nathan and Muller-Landau, 2000). In fact, the importance of seed dispersal has been increasingly recognized as essential process that underlies plant community structure and dynamics (Harms et al., 2000). Typically, for any site, the seed community reflects the input of seeds of local origin, as well as the movement into a unit area by long distance immigrants (Martinez-Rammos and Soto-Castro, 1993; Harms et al., 2000). In the tropics, between 62 and 93\% of all plants are consumed by frugivores, consequently patterns of vertebrate seed deposition are widely assumed to have a direct impact on plant fitness, demography, and community structure (Jordano, 1992).

Seed rain studies that assess vertebrates as seed vectors generally estimate seed shadows of individual trees as seeds are removed from a parent plant (Laman, 1996), or measure dispersal into sites such as deforested habitats (Guevara and Laborde, 1993), or forest gaps (MartinezRammos and Soto-Castro, 1993; Loiselle et al., 1996; Wenny and Levey, 1998). In all cases the importance of these frugivores on seed rain patterns has always been confirmed (Voysey et al., 1999). In this respect, as few tropical trees produce seeds with long dormancy mechanisms (Baskin and Baskin, 1998), advanced vegetation regeneration results from relatively recent input of seeds from the seed rain, especially in abandoned pastures where the seed bank of many plant species has been depleted and a seedling bank does not exist (Slocum and Horvitz, 2000; Pausas et al., 2006). Consequently, seed dispersal events are the only source of seeds for natural regeneration (Holl, 1999, 2002). In fact, lack of dispersal has been reported as an important limitation for vegetation regeneration in pastures, or colonization of fallow land (Kollmann, 1995). Remnant trees and shrubs remaining after vegetation conversion to pasture have greater seed rain beneath their canopies than in open pasture (Guevara et al., 1986; Guevara and Laborde, 1993; Nepstad et al., 1996; Slocum and Horvitz, 2000; Holl, 2002). Many of these trees produce fleshy fruits, which attract frugivorous vertebrates to feed and rest within their fruiting canopies (Eshiamwata et al., 2006). As a result, frugivores often deposit large number of seeds from several species under remnant trees (Guevara and Laborde, 1993; Galindo-González et al., 2000; Slocum and Horvitz, 2000; Pausas et al., 2006). Then, the presence of trees may contribute to the recovery of environmental conditions favorable to tree regeneration processes (Parrotta et al., 1997; Lamb et al., 2005). A first consequence of improved environmental conditions is the high seedling establishment beneath remnants trees in comparison with adjacent areas of open pastures (Guevara et al., 1992; Zahawi and Augspurger, 1999; Slocum and Horvitz, 2000; Slocum, 2001).
Habitat fragmentation has serious consequences for local communities, especially animal movements, which may be inhibited by cleared areas such as pastures or recent clear-cuts (Davies et al., 2000). The mobility and ecological capacity of animals to cross deforested areas and to exploit new habitats is directly related to their tolerance to the fragmentation process (Newell, 1999). Flight allows bats to cover large distances in short periods of time, crossing different vegetation types and landscapes that could constitute physical barriers for other species of mammals (Arita and Fenton, 1997). In contrast to other groups such as primates and understory birds (Lemos de Sá et al., 1990; Silva et al., 1996), many bat species, and particularly generalist ones, can persist in fragmented landscapes in the tropical areas (Law et al., 1999; Aguirre et al., 2003). This apparent tolerance to fragmentation is explained by the ability of bats to cross habitat boundaries and to fly over open areas to reach resources that are patchy in space and time (Montiel et al., 2006).

Few studies have documented the role of frugivorous bats in the dispersal of large seeded species, which they cannot ingest (Lopez and Vaughan, 2004; Melo et al., 2009). Such fruits are usually processed by bats in feeding roosts under which seeds are deposited after pulp consumption (Melo et al., 2009). In the tropical forests frugivorous bats often use leaves of understory species (e.g., palms, Carludovica, Asplundia, Heliconia, Calathea, Philodendron, and Rhodospatha; Chaverri and Kunz, 2006; Melo et al., 2009), as feeding roost. However, in forest areas converted into pastures, bats may use remnant trees as feeding roosts (Slocum and Horvitz, 2000). In cleared Cerrado (Neotropical savanna; Ribeiro and Walter, 1998), bats also use the canopy of remnant trees as feeding roosts (J. Ragusa-Netto, pers. obs.). Therefore, those trees might be functioning as 'recruitment foci' likewise other remnant trees within tropical pastures (Guevara et al., 1992; Guevara and Laborde, 1993; Nepstad et al., 1996; Slocum and Horvitz, 2000). By attracting frugivorous bats, potentially, these trees could contribute to the enhancement of seed arrival under their canopies and more rapid regrowth around them (Manning et al., 2006).

In this study we describe the seed rain deposited by bats under four Cerrado tree species common within pastures. Those species are similar both in size and canopy architecture, exhibiting dense foliage. However, while three of them (Buchenavia tomentosa Eichler, Couepia grandiflora (Mart. \& Zucc.) Benth., and Licania humilis Cham. \& Schltdl.), produce fleshy fruits exploited by bats, the other (Qualea grandiflora Mart.), has dry fruits with wind dispersed seeds (Lorenzi, 1998). Therefore, as frugivorous bats might often be checking these trees either for the onset of fruiting, or to exploit fruits, they, in principle, enhance their familiarity with these trees, and thereafter might use them also as feeding roost. Then, familiar trees might receive an increased seed rain under their canopies (Slocum and Horvitz, 2000). We focused on the arrival of large seeds ( $>8 \mathrm{~mm}$, Melo et al., 2009) from trees and shrubs, which have been common in the 
initial phase of Cerrado regeneration (Pott et al., 2006). Also, we analyzed the similarity among the four tree species in terms of seed rain composition, and compared the number of both seeds and seed species deposited under them. Besides that, we assessed the relationship between seed rain intensity and the density of each tree species.

\section{Material and Methods}

\subsection{Study site}

The study took place at the Santa Helena, a ranch (6000 ha) in the municipality of Três Lagoas, (State of Mato Grosso do Sul, Brazil; $4 \mathrm{~km}$ northeast of the downtown $\left(51^{\circ} 41^{\prime} \mathrm{O}, 20^{\circ} 44^{\prime} \mathrm{S}, 340 \mathrm{~m}\right.$ elevation). The climate is seasonal and marked with wet (October to March) and prolonged dry (April to September) season. Annual rainfall is approximately $1400 \mathrm{~mm}$ (70\% in the wet season), and mean annual temperature lies around $24.0^{\circ} \mathrm{C}$. The ranch was clear-cut in the early 1970s, high-graded for timber/coal, and then converted to pasture. A small private reserve (25 ha) was left, in which the original dense Cerrado vegetation is yet present, despite of perturbation (mainly in the understory) caused by cattle. During the study, stocking was around $0.5 \mathrm{head} / \mathrm{ha}$. Invading secondary growth was not controlled either in the previous or the studied year. Consequently, much of the pasture was being taken over by trees, shrubs, forbs, and ferns. There were over forty species of trees and shrubs in the pasture, which constituted potential sources of seeds (J. Ragusa-Netto, pers. obs.). The most common included the early-successional shrubs Duguetia furfuracea (A. St.-Hill) Saff, Strichnos brasiliensis Mart., Waltheria indica L., Mimosa polycarpa Kunth., Mimosa hebecarpa Benth., Diospyros hispida DC., and Vernonia ferruginea Less. Trees left in the pasture as timber reserves or as shade trees included Caryocar brasiliense Cambess., Qualea parviflora Mart., Q. grandiflora, Licania humilis, Couepia grandiflora, Pouteria ramiflora (Mart.) Radlk., Buchenavia tomentosa, Annona coriacea Mart., Eschweirela nana Miers, and Copaifera langsdorffi Desf. (J. Ragusa-Netto, pers. obs.).

Selection of study tree species. Among the selected tree species, three of them bore fleshy fruits exploited by bats (Licania humilis, Couepia grandiflora, Buchenavia tomentosa), and exhibit dense foliage, while differ mainly both in size and leaf loss process (J. Ragusa-Netto, unpublished results). Qualea grandiflora also exhibit dense foliage and shed its leaves at the end of the dry season. However, bore dry fruits containing seeds that are wind-dispersed, while native bees pollinated their flowers (Lorenzi, 1998). Because bats have no feeding relationship with $Q$. grandiflora, we used it as a control. Dense canopies have many spreading, overlapping branches that may provide bats with good shelter. In this respect, leaf loss process might differ between species in the course of the dry season, so that bare canopies might become differently unsuitable as feeding roost for bats (Janzen et al., 1976). In the pasture we randomly selected 10 mature trees (DBH [diameter at breast height] $>30 \mathrm{~cm}$ ) of each species for data collection. We avoided smaller trees due to potential size differences in providing shelter to bats. We measured a series of traits from tree architecture (DBH, tree and trunk height, canopy area and volume, and foliage abundance), assuming circularity of canopy shape. Selected trees were at least $50 \mathrm{~m}$ apart from each other and all of them were within a pasture band $(2000 \times 300 \mathrm{~m})$, with distances ranging from 400 to $700 \mathrm{~m}$ from the private reserve. Trees present in this band were at intermediate distance between the private reserve and one of the farm edges, where there was a paved road.

\subsection{Seed rain sampling}

Every month at the ground under the canopies of sampled trees we first carefully removed the leaf litter and collected all seeds $>8 \mathrm{~mm}$ in length. This cutoff criterion was based on the ability to identify collected seeds without germination treatments. Seeds, smaller than this threshold, were more likely to be rapidly buried and were often covered by fungus or were too deteriorated to be reliably assigned to species or morphospecies (Melo et al., 2009). No buried seeds were collected to avoid including seeds from the parent tree or deposited by other seed vector which identity was difficult. Also, as we did not use seed traps, while looking for seeds the smallest ones might be overlooked. We were fairly confident that most seeds and fruits were found because they were large and the ground beneath the trees was largely bare of vegetation. The seed samples were placed on drying paper and stored in properly labeled plastic bags. Once back in the laboratory, the seeds were identified using a reference collection that was compared with specimens in the Herbarium of UFMS-Campus Três Lagoas. In the count of seeds we did not consider the fruits dispersed by wind, birds, and other vertebrates, or those fruits that fell directly from the tree. Because we were interested in the seed rain generated by effective seed dispersal, that is, the movement of seeds away from parent plants, and not in seeds that were simply dropped beneath a parent tree without being dispersed, for most of the analyses, unless otherwise noted, we did not consider seeds that had been collected under a conspecific tree (hereafter "undispersed seeds"; see Slocum and Horvitz, 2000, for a similar procedure). In the last case we identified those fruits by their simultaneous presence in the canopy and the absence of marks in the fruit pulp. However, we counted the seeds whenever bat teeth marks were present and the sampled tree produced no fruit. We easily distinguished bat dispersed diaspores because bat teeth marks clearly differ from those of rodents and parrots bill. All such marks were conspicuous on the partially eaten flesh of the dropped fruits (Hardesty and Parker, 2003; Clark et al., 2004). We also distinguished seeds or fruits dispersed by other vectors by the presence of white uric acid which indicated bird defecation, whereas seeds completely clean of an aril or fruit pulp, and free of uric acid indicated bird regurgitation. Fox scats were rare although easily identifiable. Those intact seeds or fruits that have visible 
teeth, claw or bill marks were assumed as dispersed by unknown vertebrate vector. Wind- or ballistically dispersed seeds were distinguished, if necessary, by comparison using the reference collection. We recorded seed rain all year, from the beginning of the dry season (April 2010) to the end of the rainy season (March 2011).

\subsection{Leaf abundance}

Due to the potential variation in feeding roost use by bats according to leaf abundance in the canopy (Janzen et al., 1976), monthly, from April 2010 to March 2011 we monitored individual crowns for the presence of leaves. The abundance of leaves was ranked on a relative scale, ranging from total absence (0) to a plentiful canopy (4; Fournier, 1974). Thus, for each tree species, the sum of scores resulted in a monthly index of leaf abundance. Then, we correlated this parameter with seed abundance under the canopy.

\subsection{Tree species density}

In principle generalist frugivorous bats might use remnant trees as feeding roost according to their abundance (Chaverri and Kunz, 2006). Then, variation in tree species use and respective seed rain abundance might mirror remnant tree species abundance. To assess the relationship between tree species density and amount of seed rain, we sampled tree species density using the point center quadrant technique (Krebs, 1989). For that, we established 15 parallel transects (length $=500 \mathrm{~m}$, and $150 \mathrm{~m}$ apart one from each other), in which we positioned 10 points (each $50 \mathrm{~m}$ apart from the other, total $=150$ points). At each point we sampled the four closest trees with $\mathrm{DBH} \geq 20 \mathrm{~cm}$ (potentially mature trees). We sampled tree density in May 2011, after to conclude seed collection.

\subsection{Data analysis}

To compare tree species density we used ANOVA (Analysis of Variance). We took as replicate transect based density of each tree species. This data were Box-Cox transformed to achieve normality and reduce heteroscedasticity (Shapiro-Wilk test, $W=0.956, P=0.070$ ). In seasonal vegetation there is a trend for tree species to be clumped in distribution (Hubbell, 1979). Therefore, the focused remnant tree species might also be aggregated causing high patchiness of seed rain according to tree species used as feeding roost by bats. Then, we used a standardized Morisita's Index of Dispersion (Morisita, 1962) to evaluate the distribution patterns of the four tree species in the sampled area. This index ranges from -1.0 to +1.0 , with $95 \%$ confidence limits at +0.5 and -0.5 . Random patterns give an $I_{p}=0$, clumped patterns an $I_{p}>0$, and uniform patterns an $I_{P}<0$ (Krebs, 1989). In this analyses we took the number of trees per species sampled at every point of each transect. Also, we performed Chi-square contingency analysis to test for differences in the number of trees per species present in each transect. In a contingency table rows (here transects) represent the different states of one nominal variable, columns (tree species) represent the states of another nominal variable, and cells contain the counts of occurrences of that specific state (row, column) of the two variables. The significance of association between the two variables (based on chi-squared) is then given, with $p$ values from the chi-squared distribution. The contingency table analysis then gives information on whether the two variables are associated. In this analyses we took the accumulated number of trees per species sampled at each transect. Due to differences in the canopy projection area of sampled trees, both the number of seeds and seed species were compared by ANCOVA(Analysis of Covariance), in which we took as replicate the respective totals obtained all year-round under every tree. ANCOVA can be compared with ANOVA, but has the added feature that for each group, variance that can be explained by a specified covariate is removed. Both canopy projection area and seed number were also Box-Cox transformed to achieve normality and to reduce heteroscedasticity (Shapiro-Wilk test, $\mathrm{W}=0.972, \mathrm{p}=0.421, \mathrm{~W}=0.968$, $\mathrm{p}=0.316$, respectively). To analyze the relationship between leaves abundance in trees and the number of seeds deposited under them we used the non-parametric Spearman Rank Correlation. We performed Principal Component Analysis (PCA) with tree variables (tree and trunk height, DBH, canopy volume, and foliage abundance), of the four species to explore the segregation among species and to identify variables most strongly correlated to groups. We used an analysis of similarity (ANOSIM) to test for differences in the seed rain composition among tree species sampled as bat feeding roosts. The ANOSIM procedure uses Monte Carlo randomization of observed data to assess whether rank similarities within groups (10 trees from every species) are greater than between groups (every tree species). The Bray-Curtis index (one of the most robust measures for this purpose Faith et al., 1987) was used to express similarities and 10000 Monte Carlo permutations were conducted to generate a random test statistic. If the ANOSIM was significant, to analyze the compositional differences among seed rains under the 40 studied trees, we used the non-metric multidimensional scaling (NMDS) ordination technique. As a similarity measure, the Bray-Curtis coefficient was also used. Then, we conducted a Correspondence Analysis (CA) to explore the variation on the spatial association between seed rain composition and tree species used as feeding roosts.

\section{Results}

In the pasture we recorded a total of 32 tree species of 17 families. The most common trees belonged to Annonaceae, Caryocaraceae, Chrysobalanaceae, Combretaceae, Leguminosae and Vochysiaceae. The four species sampled as feeding roosts (Buchenavia tomentosa: Combretaceae $3.10 \pm 0.96$ trees/ha, Couepia grandiflora: Chrysobalanaceae $6.53 \pm 2.64$, Licania humilis: Chrysobalanaceae 6.07 \pm 1.84 , and Qualea grandiflora: Vochysiaceae $4.12 \pm 0.77)$, exhibited no density difference $(\mathrm{F}=0.688, \mathrm{p}=0.564)$. Moreover, trees from the focused species were scattered across the sampled area, as they exhibited a trend either for 
random (Licania humilis, Ip $=0.12$; Couepia grandiflora, Ip $=0.09$ ), or uniform distribution (Buchenavia tomentosa, Ip $=-0.33 ;$ Qualea grandiflora, Ip $=-0.79)$. Also, no significant association emerged between tree species and transects (Chi-square contingency analysis, $\chi^{2}=53.80$, $\mathrm{df}=42, \mathrm{p}=0.110)$.

We recorded seed rain under canopies of all sampled species and trees. Thus, we found a total of 6162 seeds from 32 species. After excluding seeds originating from fruiting trees and those dispersed by birds and abiotic means we included in the analyses a total of 4892 seeds from 11 species. These animal-dispersed seed species comprised trees, and scrubs associated in different successional stages within the pasture. All these seeds showed signs of manipulation, such as bat tooth marks and total or partial removal of pulp/arils from seeds. Six of 11 seed species had a total of 60 or more seeds and comprised $95.8 \%$ of all seeds recorded under all canopies. Strychnos brasiliensis accounted for $48.6 \%$ of all seeds collected $(n=2377)$ under canopies, followed by Duguetia furfuracea with $39.9 \%$ $(\mathrm{n}=1951)$ of all seeds. Only these more abundant seed species occurred under all canopies. Remaining seed species $(11.5 \% ; \mathrm{n}=564)$ occurred at moderate or low abundances (e.g., 177 Andira cuyabensis Benth., and 6 Buchenavia tomentosa seeds). During the year seed deposition varied substantially with a maximum of 1026 seeds deposited in July, when leaf loss was intense, and a minimum of 83 in October, when flushing progressed. Therefore, we found no consistent pattern between both seed and leaf abundance (Spearman correlation, $r_{s}=-0.46, p=0.130$ ). In fact, seed and leaf abundance were inversely correlated in L. humilis $\left(\mathrm{r}_{\mathrm{s}}=-0.790, \mathrm{p}=0.003\right)$, and C. grandiflora $\left(\mathrm{r}_{\mathrm{s}}=-0.794\right.$, $\mathrm{p}=0.004)$, although unrelated in B. tomentosa $\left(\mathrm{r}_{\mathrm{s}}=0.120\right.$, $\mathrm{p}=0.707)$, and positively correlated in $Q$. grandiflora $\left(\mathrm{r}_{\mathrm{s}}=0.593, \mathrm{p}=0.048\right)$.

Under Couepia grandiflora, we recorded a total of 1374 seeds from 11 species (monthly, from 24 to 276 , and from 4 to 8 , respectively; mean $\pm \mathrm{sd}, 137.4 \pm 85.1$, and $6.5 \pm 1.4$, respectively), under Buchenavia tomentosa 1563 seeds from 10 species (from 58 to 456, and from 4 to 8, respectively, $156.3 \pm 123.7$, and $5.6 \pm 1.3$ ), under Qualea grandiflora 1321 seeds from 10 species (from 38 to 307, and from 3 to 10 , respectively $132.1 \pm 97.0$, and $5.5 \pm 2.3$ ), and under Licania humilis 634 seeds from 8 species (from 14 to 120 , and from 3 to 6 , respectively $63.4 \pm 37.0$, and $4.6 \pm 0.8$ ). In this respect, both seed abundance and number of species differed significantly, so that Licania humilis had the smallest adjusted means of both parameters (ANCOVA, $\mathrm{F}=4.77, \mathrm{p}=0.007$, and $\mathrm{F}=3.10, \mathrm{p}=0.040)$.

Principal component analysis extracted two factors, which together accounted for $98.2 \%$ of variation in the four tree readings. PC 1 (eigenvalue $=2.2$ ) was strongly positively correlated with canopy volume $(\mathrm{r}=0.91)$, tree height $(\mathrm{r}=0.89)$, and trunk height $(\mathrm{r}=0.71)$. Trees from every species were ordinate along this axis, although no coherent group may be distinguished (Figure 1). PC 2 (eigenvalue $=1.71$ ) was positively correlated with leaf density $(r=0.94)$, and trunk height $(r=0.68)$. This axis positioned $C$. grandiflora trees as a coherent group, while trees from the other species exhibited no consistent dissimilarity (Figure 1).

Differences in seed rain composition were greater among than within tree species (ANOSIM, $\mathrm{r}=0.30$, $\mathrm{p}=0.0001)$. This result reflected the coherence of trees

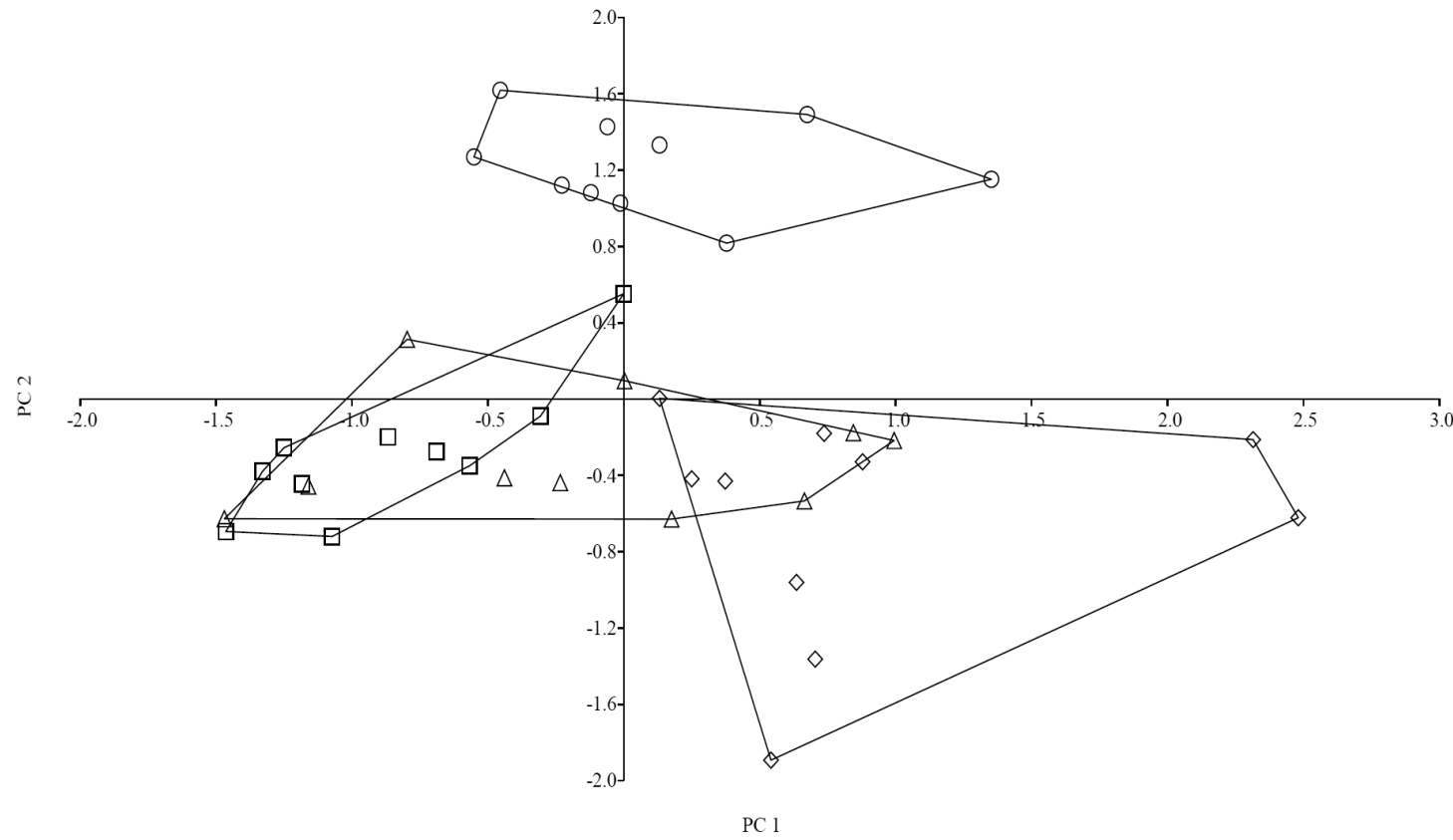

Figure 1. Principal Component Analysis (PCA) ordination plot on tree species traits (architecture). Buchenavia tomentosa trees: diamonds, Couepia grandiflora: circles, Licania humilis: squares, and Qualea grandiflora: triangles. 
dispersion in the ordination plot according to seed rain composition under each tree species, so that Buchenavia tomentosa together with Qualea grandiflora were distinctly separated from Couepia grandiflora and Licania humilis at opposite ends of the ordination diagram (NMDS ordination: stress $=0.064$; Figure 2 ). In principle, each double of tree species shared more similar complements of their seed rain than with the other double. In fact, at least two seed sub-communities could thus be distinguished according to tree species used by bats as feeding roost. One related to Couepia grandiflora and Licania humilis, and the other to Buchenavia tomentosa and Qualea grandiflora. This may be shown by a correspondence analysis explaining $97.3 \%$ of the cumulative percentage of total variation attributed to the matrix tree species vs seeds deposited. Licania humilis, Strychnos brasiliensis, Buchenavia tomentosa, and Couepia grandiflora seeds were deposited mainly under Buchenavia tomentosa and Qualea grandiflora trees. In contrast, Duguetia furfuracea, Andira cuyabensis, Caryocar brasiliensis, Simarouba versicolor St. Hill., Anonna nuttans R. E. Fr., Pouteria torta (Mart.) Radlk, and Eschweilera nana Miers seeds occurred mainly under Couepia grandiflora and Licania humilis trees (Figure 3). Finally, because PC 2 and NMDS 1 separated coherent groups (tree species according to tree parameters Figure 1, and seed species composition under

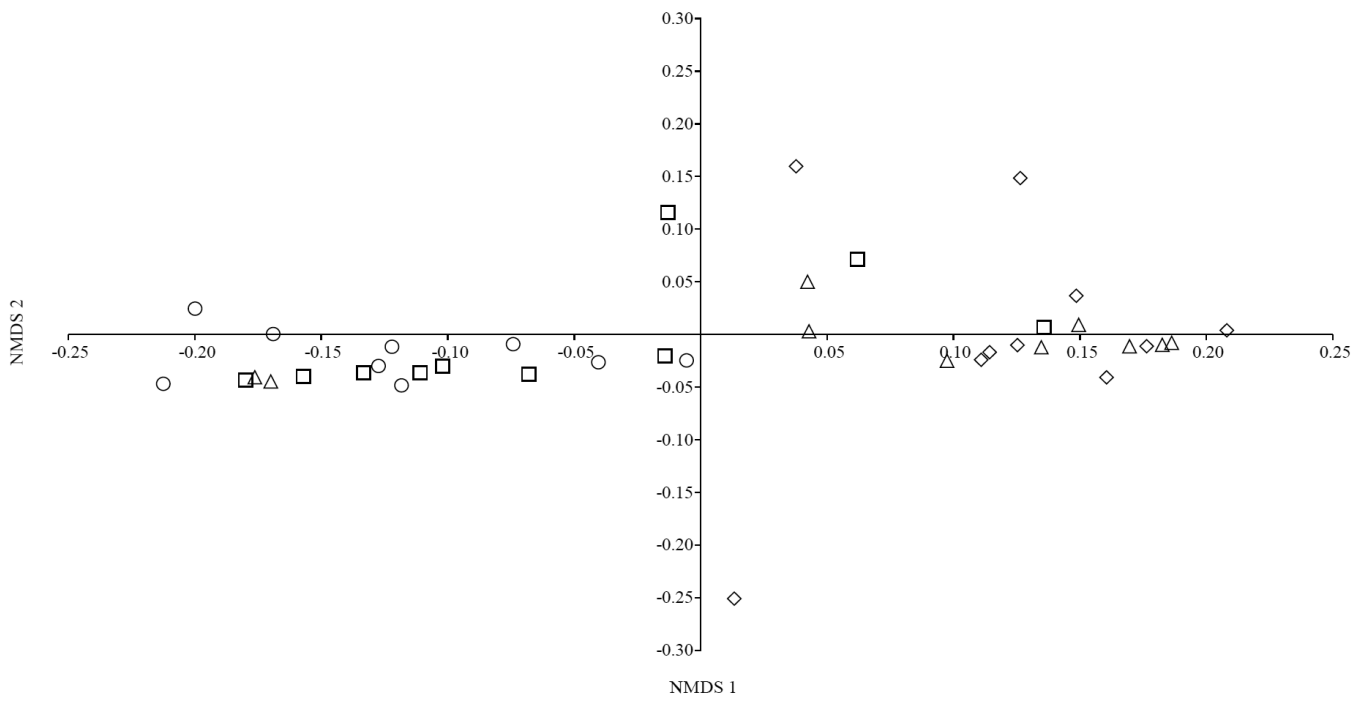

Figure 2. Non-metric multi-dimensional scaling (NMDS; stress $=0.064$ ) ordination plot of seed communities recorded under cerrado remnant trees in a pasture in Central Brazil. Seeds under Buchenavia tomentosa trees: diamonds, Couepia grandiflora: circles, Licania humilis: squares, and Qualea grandiflora: triangles.

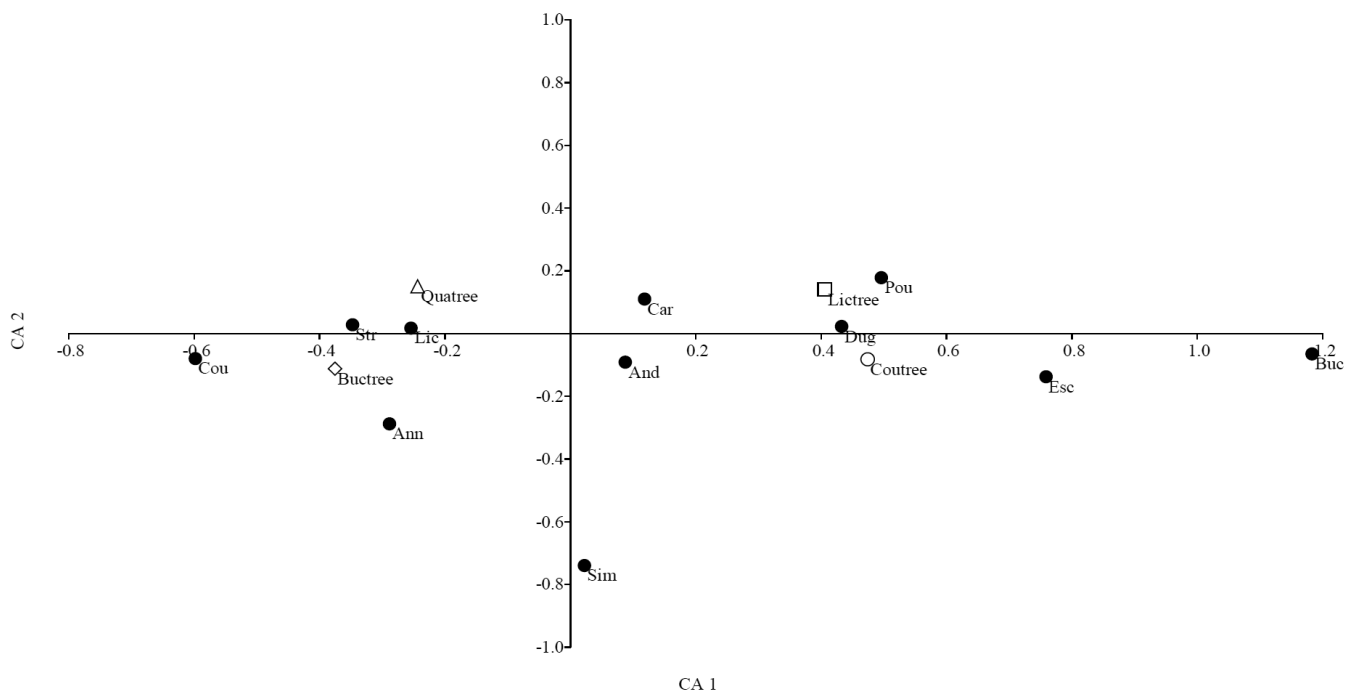

Figure 3. Correspondence analysis (CA) ordination plot in which full circles denote seed species overlapping tree species used by bats as feeding roosts. (Buchenavia tomentosa trees: diamonds, Couepia grandiflora: circles, Licania humilis: squares, and Qualea grandiflora: triangles. Species are represented by the first three letters of their genera names). 
tree species Figure 2, respectively), we correlated these axis to assess the relationship between the similarity in seed composition and tree architecture. A negative and significant correlation emerged $\left(r_{s}=-0.40, p=0.015\right)$, in which seed composition similarity decrease according to leaf abundance and trunk height (see above).

\section{Discussion}

The four studied tree species had moderate resistant wood (Lorenzi, 1998). Therefore, cattle shading may be the major cause for their maintenance in the pasture. Farmers manage pastures retaining a substantial number of trees from original vegetation to promote suitable conditions for cattle. Presumably, the adequacy of the dense canopy of the four species favored their maintenance in the pasture which consequence was their similar density and the absence of clumped dispersion patterns. In principle, frugivorous bats might use tree species as feeding roosts according to their relative abundance. However, only according to tree species densities the intensity of seed rain under the four species might be balanced. The differences in seed rain suggest major importance of other parameters (see below). Importantly, scattered trees are used by a wide range of animals because the micro-ecosystem surrounding an individual tree greatly enhances structural complexity relative to its surrounds. Particularly, frugivorous bats make extensive use of scattered trees in many tropical landscapes (Galindo-González et al., 2000). The intense seed rain recorded under the studied trees indicates their importance, at least, as feeding roosts.

The seed assemblages deposited by bats under remnant trees were highly variable and diverse. Despite of the heterogeneity either within or between tree species, all of them received seeds throughout the year. Moreover, seed rain was dominated by a small number of species, which were represented by large number of seeds. In spite of that, areas under Licania humilis trees received smaller numbers of seeds and seed species than the other trees. Licania humilis trees clumped at extreme left of PC 1, highly correlated with tree and trunk height, besides canopy volume. These parameters indicate them as the smallest trees, perhaps less attractive to bats. It is possible that Licania humilis provided reduced shelter for feeding bats. However, it is important to emphasize the crude assess on canopy closure. Despite of sampling tree parameters with potential importance for bats, presumably, unrecorded traits may be crucial for bats as they deposited substantial amounts of seeds when trees had bare canopies. Thus, it appears that other factors than, for example, leaf abundance might be important for seed arrival. In fact, for some species, the amount of seed rain was inversely related to leaf density, an unexpected result due to the generalized use of leafy canopies as feeding roost (Janzen et al., 1976). Perhaps, bats often use those tree species for roosting (J. Ragusa-Netto, pers. obs.), and also for feeding purposes (Evelyn and Stiles, 2003). Even then, under leafy canopies seed rain was more diverse, in principle, due to the coincidence with the availability of high fruiting diversity, and the attraction of a wide spectrum of bat species. Importantly, the production of fleshy fruits by a species was not a central factor associated to seed arrival, as seeds frequently arrived under Qualea grandiflora trees.

The variability of seed rain composition under any particular tree and the range of actual seed fall into a particular species indicate patchiness in seed rain. This might be consequence of seed shadows from fruit patches over a range of distances, and seed input from long distance dispersal. Despite of the heterogeneity in seed rain input, trees from a given species exhibited substantial similarity in seed rain composition, indicating nonrandom patterns of seed rain. In fact, major differences emerged between two pairs of tree species (Licania humilis, and Couepia grandiflora against Buchenavia tomentosa, and Qualea grandiflora). As general pattern, the two most abundant seed species were differently associated with those pairs. While Duguetia furfuracea predominated under the first, Strychnos brasiliense was common under the second pair. Moreover, some large seed species were deposited almost exclusively under trees of one pair (e.g. Pouteria torta seeds under the first, and Couepia grandiflora under the second pair). As mentioned above, seed species abundance under a particular tree species might mostly be related to the distance of seed source, or dispersal vectors, which select roosts according to particular traits (Evelyn and Stiles, 2003). Either small or large frugivorous bats may have similar dietary habits, although substantial differences are common (Giannini and Kalko, 2004; Silva et al., 2008). Hence, it is not surprising that many seed species were deposited under all tree species and individuals. Thus, it is important to consider as much as possible the influence of both seed vectors and microsites on seed rain heterogeneity. Moreover, the differences in seed rain under the four tree species suggest the importance of tree diversity, besides tree density, for a rich and abundant seed rain in pastures. Presumably, the different taxa of trees will attract more kinds of bats and other dispersers, which might enhance seed arrival to remnant trees (Nepstad et al., 1991; Begnini and Castellani, 2013; Blackham et al., 2013). These factors might have consequences on the dynamics of Cerrado regeneration favoring heterogeneity of future Cerrado tree community. This patchiness distribution has been assumed important in stressful habitats for improving tropical diversity (Jordano and Schupp, 2000).

The location of a restoration site within the landscape often plays a critical role in determining seed rain dynamics. Some studies in the tropics have demonstrated the importance of remnant forest proximity for dispersal and establishment of zoochorous plants (Zanne and Chapman, 2001; Ferguson et al., 2003). However, in other cases the relationship between seed dispersal success and distances from forests exhibited no consistent trends (Guevara et al., 1986; Slocum and Horvitz, 2000; Slocum, 2001; Zahawi and Augspurger, 2006; Cole et al., 2010). Although we did not sample the role of potential seed sources to the observed seed rain, the contribution of local sources 
might be important as observed elsewhere (Cole et al., 2010; Blackham et al., 2013). In fact, we found that the majority of diaspores arriving to the focused trees were from only two early-successional shrub species $(88.5 \%$, Strychnos brasiliensis, and Duguetia furfuracea; Pott et al., 2006). Both were not restricted to the private reserve, and were very common within the pasture (J. Ragusa-Netto, pers. obs.). In spite of the substantial presence of other large-seeded species, our results support the findings of previous studies in tropical ecosystems showing that early-successional species tend to be common in the seed rain in human-altered tropical lands (Holl, 1999; Martínez-Garza and Howe, 2003; Blackham et al., 2013). It is important to emphasize that the largest seeds present in our sample belong to tree species which were present either in the pasture or private reserve, potentially, the major seed sources (J. Ragusa-Netto, pers. obs.).

Dispersal of large seeds by bats is assumed as highly important in areas from where large frugivores have been depleted or extirpated due to hunting or habitat loss (Wright et al., 2007). Other seed dispersers seldom move large seeds far into deforested areas, whereas bat-dispersed plants can have high seed inputs (Hooper et al., 2002). Seed deposition by bats under remnant trees in pastures may promote seedling establishment of large-seeded species, which are not dispersed by flying bats (Melo et al., 2009), well known by dispersing small seeds (Lopez and Vaughan, 2004). Much of these diaspores have comparatively low establishment success in pastures, while large seeds can have relatively high germination and establishment rates (Nepstad et al., 1996; Hooper et al., 2002; but see Lopez and Vaughan, 2004). In this respect, isolated trees may act as nuclei for forest recovery and can be a valuable and inexpensive tool for the reforestation of Neotropical habitats (Galindo-González et al., 2000). The concept of "nucleation" is used to describe the spreading of recovery from many different foci following a disturbance, wherein scattered trees play an important role (Franklin and MacMahon, 2000). In pastures, scattered trees can act as "regeneration nuclei" (Guevara et al., 1986), from which plant succession may radiate outwards into other parts of a given landscape (Toh et al., 1999).

The data presented here is based only on one large pasture and a small number of remnant tree species. However, both the abundance and number of large seed species recorded in the seed rain were high. Hence, the overall results appear to be consistent in terms of a substantial and diverse seed rain generated by bats in a highly anthropized landscape. This is the first study focusing on seed rain generated by bats in the domains of Brazilian Cerrado, one of the most endangered biomes in the world. Knowledge concerning regeneration sources in disturbed areas can provide useful information for the management and conservation of this savanna-like vegetation. Increasing the density of trees within pastures might, at least, improve the role of this modified habitat as ecological corridors. Despite of reduced genetic variability, scattered trees represent potential sources for large-scale natural regeneration, which is cheaper and ecologically preferable form of restoration than tree planting (Spooner et al., 2002). Thus, by preserving a dense and diverse collection of remnant trees within today's pastures may contribute to a faster Cerrado recovery in extensive areas that can be reclaimed for restoration in the future.

\section{Acknowledgements}

The authors are grateful to Jefferson Salomão for the permission to work in the Sta Helena farm. Juliana Rodrigues, Nayla Silva, Jodelma Manvailer, and Daiane Lima kindly provided field assistance. Financial support was provided by FUNDECT and CNPq.

\section{References}

AGUIRRE, L.F., LENS, L., VAN DAMME, R. and MATTHYSEN, E., 2003. Consistency and variation in the bat assemblages inhabiting two forest islands within a Neotropical savanna in Bolivia. Journal of Tropical Ecology, vol. 19, no. 4, pp. 367-374. http://dx.doi.org/10.1017/S0266467403003419.

ARITA, H.T. and FENTON, M.B., 1997. Flight and echolocation in the ecology and evolution of bats. Trends in Ecology \& Evolution, vol. 12, no. 2, pp. 53-58. http://dx.doi.org/10.1016/ S0169-5347(96)10058-6. PMid:21237972.

BASKIN, C.C. and BASKIN, J.M., 1998. Seeds: ecology, biogeography, and evolution of dormancy and germination. San Diego, USA: Academic Press. 666 p.

BEGNINI, R.M. and CASTELLANI, T.T., 2013. Seed rain under the canopies of female and male Myrsine coriacea, a pioneer tree from the Brazilian Atlantic forest. Journal of Tropical Ecology, vol. 29, no. 5, pp. 391-399. http://dx.doi.org/10.1017/ S0266467413000400.

BLACKHAM, G.V., THOMAS, A., WEBB, E.L. and CORLETT, R.T., 2013. Seed rain into a degraded tropical peatland in Central Kalimantan, Indonesia. Biological Conservation, vol. 167, pp. 215-223. http://dx.doi.org/10.1016/j.biocon.2013.08.015

CHAVERRI, G. and KUNZ, T.H., 2006. Roosting ecology of the tent-roosting bat Artibeus watsoni (Chiroptera: Phyllostomidae) in Southwestern Costa Rica. Biotropica, vol. 38, pp. 77-84.

CLARK, C.J., POULSEN, J.R., CONNOR, E.F. and PARKER, V.T., 2004. Fruiting trees as dispersal foci in a semi-deciduous tropical forest. Oecologia, vol. 139, no. 1, pp. 66-75. http://dx.doi. org/10.1007/s00442-003-1483-1. PMid:14745649.

COLE, R.J., HOLL, K.D. and ZAHAWI, R.A., 2010. Seed rain under tree islands planted to restore degraded lands in a tropical agricultural landscape. Ecological Applications, vol. 20, no. 5, pp. 1255-1269. http://dx.doi.org/10.1890/09-0714.1. PMid:20666248.

DAVIES, K.F., MARGULES, C.R. and LAWRENCE, J.F., 2000. Which traits of species predict population declines in experimental forest fragments? Ecology, vol. 81, no. 5, pp. 1450-1461. http:// dx.doi.org/10.1890/0012-9658(2000)081[1450:WTOSPP]2.0.CO;2.

ESHIAMWATA, G.W., BERENS, D.G., BLEHER, B., DEAN, W.R.J. and BÖHNING-GAESE, K., 2006. Bird assemblages in isolated Ficus trees in Kenyan farmland. Journal of Tropical Ecology, vol. 22, no. 6, pp. 723-726. http://dx.doi.org/10.1017/ S0266467406003646. 
EVELYN, M.J. and STILES, D.A., 2003. Roosting requirements of two frugivorous bats (Sturnira lilium and Arbiteus intermedius) in fragmented neotropical forest. Biotropica, vol. 35, no. 3, pp. 405-418. http://dx.doi.org/10.1111/j.1744-7429.2003.tb00594.x.

FAITH, D.P., MINCHIN, P.R. and BELBIN, L., 1987. Compositional dissimilarity as a robust measure of ecological distance. Vegetatio, vol. 69, no. 1-3, pp. 57-68. http://dx.doi.org/10.1007/BF00038687.

FERGUSON, B.G., VANDERMEER, J., MORALES, H. and GRIFFITH, D.M., 2003. Post-agricultural succession in El Petén, Guatemala. Conservation Biology, vol. 17, no. 3, pp. 818-828. http://dx.doi.org/10.1046/j.1523-1739.2003.01265.x.

FOURNIER, L.A., 1974. Un método cuantitativo para la medición de características fenológicas en arboles. Turrialba, vol. 24, pp. 422-423.

FRANKLIN, J.F. and MACMAHON, J.A., 2000. Messages from the mountain. Science, vol. 288, no. 5469, pp. 1183-1185. http:// dx.doi.org/10.1126/science.288.5469.1183.

GALINDO-GONZÁLEZ, J., GUEVARA, S. and SOSA, V.J., 2000. Bat- and bird-generated seed rains at isolated trees in pastures in a tropical rainforest. Conservation Biology, vol. 14, no. 6, pp. 1693-1703. http://dx.doi.org/10.1046/j.1523-1739.2000.99072.x.

GIANNINI, N.P. and KALKO, E.K.V., 2004. Trophic structure in a large assemblage of phyllostomid bats in Panama. Oikos, vol. 105 , no. 2 , pp. 209-220. http://dx.doi.org/10.1111/j.00301299.2004.12690.x.

GORCHOV, D.L., CORNEJO, F., ASCORRA, C. and JARAMILLO, M., 1993. The role of seed dispersal in the natural regeneration of rain forest after strip-cutting in the Peruvian Amazon. Vegetatio, vol. 107, pp. 339-349.

GUEVARA, S. and LABORDE, J., 1993. Monitoring seed dispersal at isolated standing trees in tropical pastures: consequences for local species availability. Vegetatio, vol. 107-108, pp. 319-338.

GUEVARA, S., MEAVE, J., MORENO-CASASOLA, P. and LABORDE, J., 1992. Floristic composition and structure of vegetation under isolated trees in neotropical pastures. Journal of Vegetation Science, vol. 3, no. 5, pp. 655-664. http://dx.doi. org/10.2307/3235833.

GUEVARA, S., PURATA, S.E. and VAN DER MAAREL, E., 1986. The role of remnant forest trees in tropical secondary succession. Vegetatio, vol. 66, pp. 77-84

HARDESTY, B.D. and PARKER, V.T., 2003. Community seed rain patterns and a comparison to adult community structure in a West African tropical forest. Plant Ecology, vol. 164, no. 1, pp. 49-64. http://dx.doi.org/10.1023/A:1021251831806.

HARMS, K.E., WRIGHT, S.J., CALDERON, O., HERNANDEZ, A. and HERRE, E.A., 2000. Pervasive density-dependent recruitment enhances seedling diversity in a tropical forest. Nature, vol. 404, no. 6777, pp. 493-495. http://dx.doi.org/10.1038/35006630. PMid:10761916.

HOLL, K.D., 2002. Effect of shrubs on tree seedling establishment in an abandoned tropical pasture. Journal of Ecology, vol. 90, no. 1, pp. 179-187. http://dx.doi.org/10.1046/j.0022-0477.2001.00637.x.

HOLL, K.H., 1999. Factors limiting tropical rain forest regeneration in abandoned pastures: seed rain, seed germination, microclimate and soil. Biotropica, vol. 31, no. 2, pp. 229-242. http://dx.doi. org/10.1111/j.1744-7429.1999.tb00135.x.

HOOPER, E., CONDIT, R. and LEGENDRE, P., 2002. Responses of 20 native tree species to reforestation strategies for abandoned farmland in Panama. Ecological Applications, vol. 12, no. 6, pp. 1626-1641. http://dx.doi.org/10.1890/1051-0761(2002)012[1626:RO NTST]2.0.CO;2.

HUBBELL, S.P., 1979. Tree dispersion, abundance, and diversity in a tropical dry forest. Science, vol. 203, no. 4387, pp. 1299-1309. http://dx.doi.org/10.1126/science.203.4387.1299. PMid:17780463.

JANZEN, D.H., MILLER, G.A., HACKFORTH-JONES, J., POND, C.M., HOOPER, K. and JANOS, D.P., 1976. Two Costa Rican bat-generated seed shadows of Andira inermis (Leguminoseae). Ecology, vol. 57, no. 5, pp. 1068-1075. http:// dx.doi.org/10.2307/1941072.

JORDANO, P. and SCHUPP, E.W., 2000. Seed disperser effectiveness: the quantity component and patterns of seed rain for Prunus mahaleb. Ecological Monographs, vol. 70, no. 4, pp. 591-615. http://dx.doi.org/10.1890/0012-9615(2000)070[0591:SD ETQC]2.0.CO;2.

JORDANO, P., 1992. Fruits and frugivory. In: M. FENNER, ed. Seeds: the ecology of regeneration in plant communities. Wallingford, UK: Commonwealth Agricultural Bureau International, pp. 105-156.

KOLLMANN, J., 1995. Regeneration window for fleshy-fruited plants during scrub development on abandoned grassland. Ecosine, vol. 2, pp. 213-222.

KREBS, C.J., 1989. Ecological methodology. New York: Harper \& Row. 654 p.

LAMAN, T.G., 1996. Ficus seed shadows in a Bornean rain forest. Oecologia, vol. 107, no. 3, pp. 347-355. http://dx.doi. org/10.1007/BF00328451

LAMB, D., ERSKINE, P.D. and PARROTTA, J.A., 2005. Restoration of degraded tropical forest landscapes. Science, vol. 310, no. 5754, pp. 1628-1632. http://dx.doi.org/10.1126/ science.1111773. PMid:16339437.

LAW, B.S., ANDERSON, J. and CHIDEL, M., 1999. Bat communities in a fragmented forest landscape on the south-west slopes of New South Wales, Australia. Biological Conservation, vol. 88, no. 3, pp. 333-345. http://dx.doi.org/10.1016/S0006-3207(98)00118-9.

LEMOS DE SÁ, R.M., POPE, T.R., GLANDER, K.E., STRUHSAKER, T.T. and DA FONSECA, G.A.B., 1990. A pilot study of genetic and morphological variation in the muriqui (Brachyteles arachnoides). Primate Conservation, vol. 11, pp. 26-30.

LOISELLE, B.A., RIBBENS, E. and VARGAS, O., 1996. Spatial and temporal variation of seed rain in a tropical lowland wet forest. Biotropica, vol. 28, no. 1, pp. 82-95. http://dx.doi. org/10.2307/2388773.

LOPEZ, J.E. and VAUGHAN, C., 2004. Observations on the role of frugivorous bats as seed dispersers in Costa Rican secondary humid forests. Acta Chiropterologica, vol. 6, no. 1, pp. 111-119. http://dx.doi.org/10.3161/001.006.0109.

LORENZI, H., 1998. Árvores Brasileiras: manual de identificação e cultivo de plantas arbóreas nativas do Brasil. Nova Odessa: Editora Plantarum. vol. 2, $320 \mathrm{p}$.

MANNING, A.D., FISCHER, J. and LINDENMAYER, D.B., 2006. Scattered trees are keystone structures-implications for conservation. Biological Conservation, vol. 132, no. 3, pp. 311321. http://dx.doi.org/10.1016/j.biocon.2006.04.023.

MARTÍNEZ-GARZA, C. and HOWE, H.F., 2003. Restoring tropical diversity: beating the time tax on species loss. Journal 
of Applied Ecology, vol. 40, no. 3, pp. 423-429. http://dx.doi. org/10.1046/j.1365-2664.2003.00819.x.

MARTINEZ-RAMMOS, M. and SOTO-CASTRO, A., 1993. Seed rain and advanced regeneration in a tropical rain forest. Vegetatio, vol. 107/108, pp. 299-318.

MELO, F.P.L., RODRIGUEZ-HERRERA, B., CHAZDON, R.L., MEDELLIN, R.A. and CEBALLOS, G.G., 2009. Small tent-roosting bats promote dispersal of large-seeded plants in a Neotropical forest. Biotropica, vol. 41, no. 6, pp. 737-743. http:// dx.doi.org/10.1111/j.1744-7429.2009.00528.x.

MONTIEL, S., ESTRADA, A. and LEÓN, P., 2006. Bat assemblages in a naturally fragmented ecosystem in the Yucatan Peninsula, Mexico: Species richness, diversity and spatio-temporal dynamics. Journal of Tropical Ecology, vol. 22, no. 3, pp. 267-276. http:// dx.doi.org/10.1017/S026646740500307X

MORISITA, M., 1962. I $\sigma$-Index, a measure of dispersion of individuals. Research on Population Ecology, vol. 4, no. 1, pp. 1-7.

NATHAN, R. and MULLER-LANDAU, H.C., 2000. Spatial patterns of seed dispersal, their determinants and consequences for recruitment. Trends in Ecology \& Evolution, vol. 15, no. 7, pp. 278-285. http://dx.doi.org/10.1016/S0169-5347(00)01874-7. PMid:10856948.

NEPSTAD, D., UHL, C. and SERRÃO, E.A.S., 1991. Recuperation of a degraded Amazonian landscape: forest recovery and agricultural restoration. Ambio, vol. 20, pp. 248-255.

NEPSTAD, D., UHL, C., PEREIRA, C.A. and SILVA, J.M.C., 1996. A comparative study of tree establishment in abandoned pasture and mature forest of eastern Amazonia. Oikos, vol. 76, no. 1, pp. 25-39. http://dx.doi.org/10.2307/3545745.

NEWELL, G.R., 1999. Responses of Lumholtz's tree-kangaroo (Dendrolagus lumholtzi) to loss of habitat within a tropical rainforest fragment. Biological Conservation, vol. 91, no. 2-3, pp. 181-189. http://dx.doi.org/10.1016/S0006-3207(99)00083-X.

PARROTTA, J., TURNBULL, J. and JONES, N., 1997. Catalyzing native forest regeneration on degraded tropical lands. Forest Ecology and Management, vol. 99, no. 1-2, pp. 1-7. http://dx.doi. org/10.1016/S0378-1127(97)00190-4.

PAUSAS, J.G., BONET, A., MAESTRE, F.T. and CLIMENT, A., 2006. The role of the perch effect on the nucleation process in Mediterranean semi-arid oldfields. Acta Oecologica, vol. 29, no. 3, pp. 346-352. http://dx.doi.org/10.1016/j.actao.2005.12.004.

POTT, A., POTT, V. and SOUZA, T.W., 2006. Plantas daninhas de pastagem na região de Cerrados. Campo Grande: Embrapa Gado de Corte. 336 p.

RIBEIRO, J.F. and WALTER, B.M.T., 1998. Fitofisionomias do cerrado. In: S.M. SANO and S.P. ALMEIDA, eds. Cerrado: ambiente e flora. Planaltina: Embrapa, pp. 89-166.

SILVA, A.G., GAONA, O. and MEDELLÍN, R.A., 2008. Diet and trophic structure in a community of fruit-eating bats in Lacandon Forest, Mexico. Journal of Mammalogy, vol. 89, no. 1, pp. 43-49. http://dx.doi.org/10.1644/06-MAMM-A-300.1.
SILVA, J.M., UHL, C. and MURRAY, G., 1996. Plant succession, landscape management, and the ecology of frugivorous birds in abandoned Amazonian pastures. Conservation Biology, vol. 10, no. 2, pp. 491-503. http://dx.doi.org/10.1046/j.15231739.1996.10020491.x.

SLOCUM, M.G. and HORVITZ, C.C., 2000. Seed arrival under different genera of trees in a neotropical pasture. Plant Ecology, vol. 149, no. 1, pp. 51-62. http://dx.doi.org/10.1023/A:1009892821864.

SLOCUM, M.G., 2001. How tree species differ as recruitment foci in a tropical pasture. Ecology, vol. 82, no. 9, pp. 2547-2559. http:// dx.doi.org/10.1890/0012-9658(2001)082[2547:HTSDA]2.0.CO;2 .

SPOONER, P., LUNT, I. and ROBINSON, W., 2002. Is fencing enough? The short-term effects of stock exclusion in remnant grassy woodlands in southern NSW. Ecological Management \& Restoration, vol. 3, no. 2, pp. 117-126. http://dx.doi.org/10.1046/ j.1442-8903.2002.00103.x.

TOH, I., GILLESPIE, M. and LAMB, D., 1999. The role of isolated trees in facilitating tree seedling recruitment at a degraded sub-tropical rainforest site. Restoration Ecology, vol. 7, no. 3, pp. 288-297. http://dx.doi.org/10.1046/j.1526-100X.1999.72022.x.

VOYSEY, B.C., MCDONALD, K.E., ROGERSC, M.E., TUTIN, E.G. and PARNELL, R.J., 1999. Gorillas and seed dispersal in the Lope reserve, Gabon: gorilla acquisition by trees. Journal of Tropical Ecology, vol. 15, no. 1, pp. 23-38. http://dx.doi. org/10.1017/S0266467499000656.

WENNY, D.G. and LEVEY, D.J., 1998. Directed seed dispersal by bellbirds in a tropical cloud forest. Proceedings of the National Academy of Sciences of the United States of America, vol. 95, no. 11, pp. 6204-6207. http://dx.doi.org/10.1073/pnas.95.11.6204. PMid:9600942.

WRIGHT, S.J., HERNANDÉZ, A. and CONDIT, R., 2007. The bushmeat harvest alters seedling banks by favoring lianas, large seeds, and seeds dispersed by bats, birds, and wind. Biotropica, vol. 39, no. 3, pp. 363-371. http://dx.doi.org/10.1111/j.17447429.2007.00289.x.

WRIGHT, S.J., MULLER-LANDAU, H.C., CALDERON, O. and HERNANDEZ, A., 2005. Annual and spatial variation in seedfall and seedling recruitment in a neotropical forest. Ecology, vol. 86, no. 4, pp. 848-860. http://dx.doi.org/10.1890/03-0750.

ZAHAWI, R.A. and AUGSPURGER, C.K., 1999. Early plant succession in abandoned pastures in Ecuador. Biotropica, vol. 31, no. 4, pp. 540-552. http://dx.doi.org/10.1111/j.1744-7429.1999. tb00401.x.

ZAHAWI, R.A. and AUGSPURGER, C.K., 2006. Tropical forest restoration: tree islands as recruitment foci in degraded lands of Honduras. Ecological Applications, vol. 16, no. 2, pp. 464-478. http://dx.doi.org/10.1890/1051-0761(2006)016[0464:TFRTIA] 2.0.CO;2. PMid: 16711037.

ZANNE, A.E. and CHAPMAN, C.A., 2001. Expediting reforestation in tropical grasslands: distance and isolation from seed sources in plantations. Ecological Applications, vol. 11, no. 6, pp. 16101621. http://dx.doi.org/10.1890/1051-0761(2001)011[1610:ER ITGD]2.0.CO;2. 